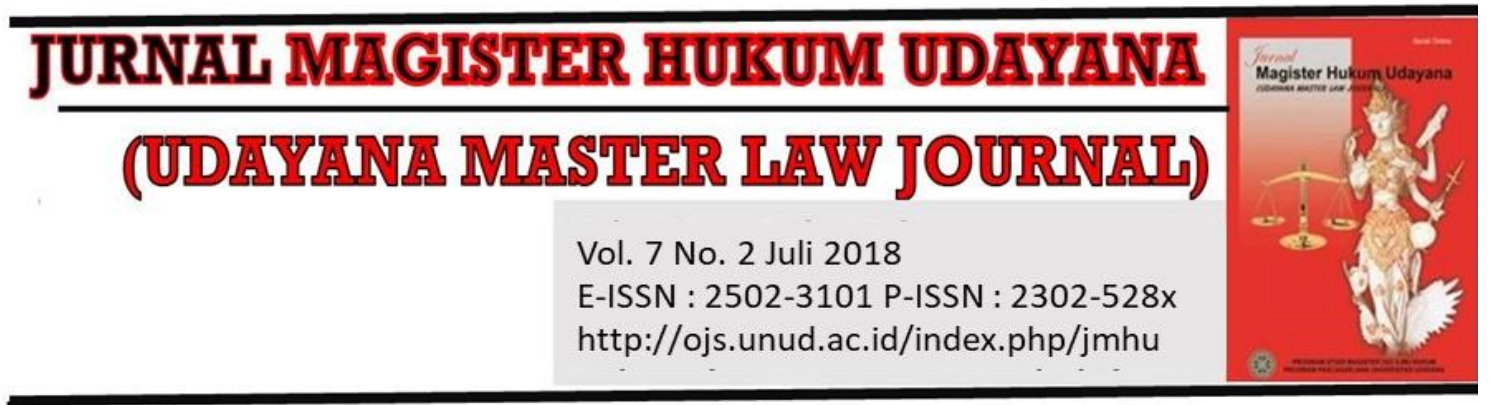

\title{
The Legal Review of Petroleum Spill Case (Pertamina Oil Spill in Kalimantan)
}

\author{
Birkah Latif ${ }^{\text {, Ade Kurniawan², Iyas Manggala Ayubi }}{ }^{3}$ \\ ${ }^{1}$ Fakultas Hukum Universitas Hasanuddin, E-mail: birkah_wan@yahoo.com \\ ${ }^{2}$ Fakultas Hukum Universitas Hasanuddin, E-mail: ade4011@gmail.com \\ 35akultas Hukum Universitas Hasanuddin, E-mail: manggalaayyubi2930@gmail.com
}

\begin{tabular}{l}
\hline Info Artikel \\
\hline Masuk: 18 Juni 2018 \\
Diterima: 13 Juli 2018 \\
Terbit: 31 Juli 2018 \\
Keywords: \\
Environment; Oil Spill; \\
Pollution; Accountability \\
\\
Corresponding Author: \\
Birkah Latif \\
E-mail: \\
birkah_wan@yahoo.com \\
\\
DOI : \\
10.24843/JMHU.2018.v07.i02 \\
.p1
\end{tabular}

Abstract
At the end of March 2018, there was an accident in the sea of
Kalimantan-Balikpapan where a Panamanian-flagged vessel
caused a leak over the oil pipeline. The pipeline connects the Crude
Lawe-lawe Terminal to Pertamina's Balikpapan Plant. As a
result, spilled oil is estimated at 40,000 barrels and resulted in five
deaths. The aim of this study is to examine the regulation on
environmental protection, especially on the oil and gas natural
resources and what form the accountability of the oil spill on the
shore. This paper is structured using a normative juridical
approach to seek solutions to legal issues arising from such
environmental cases. The study shows that the use of natural
resources, which produce metals, coal, and minerals as a source of
energy, oil and geothermal, should be based on the principles of
environmental management, namely: equity, balances, democracy
(democracy), and sustainability (sustainable) between
generations. In terms of accountability both in civil liability,
criminal, and an environment in accordance with the principle of
direct liability (strict liability) with the occurrence of
environmental pollution caused by the oil spill so legally PT
Pertamina Regional East Kalimantan may be subject to the
principle.

\section{Introduction}

Oil spills from the vessel and leakage of ships in East Kalimantan waters are one of the pollutions of the environment that endanger the life of marine ecosystems as well as human beings. Balikpapan, East Kalimantan is one of those exposed to potential

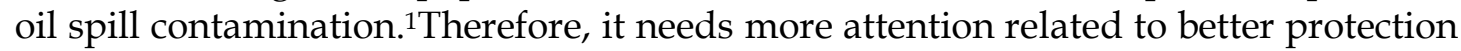
for the environment today and in the future. Relevant oil spills pollution in East Kalimantan has already investigated by the Regional Police of East Kalimantan.

The occurrence of a leakage case of Pertamina pipeline caused by coal ship MV Ever Judge, the ship was flagged Panama. In the process of investigation of Special Criminal Investigation of East Kalimantan Regional Police, the confiscated of the

1Siagian, Y. S., Rifai, A., \& Ismanto, A. (2016). Pemodelan Sebaran Tumpahan Minyak Di Perairan Teluk Balikpapan, Kalimantan Timur. Journal of Oceanography, 5(2.). p. 271 
Panamanian ship and also three-evacuation equipment of Pertamina crude oil pipeline. Three pipes totaling 49 meters long and weighing 24.5 tons are the main evidence of the cause of Pertamina crude oil spill. The alleged outbreak of Pertamina oil pipeline, allegedly due to the anchor crash MV Ever Judger ship that then caused an oil spill.

The purpose of this study, we will examine the extent of accountability for the case and to analyze the imposition of a sentence on a case that has harmed the condition of the environment and all living things that are in the vicinity. The impact of the spill on Borneo oil will certainly cause harm to society and also all the creatures that are in it and that depend on the natural surroundings. The Government of Indonesia is expected to act as soon as possible in handling cases of pollution, especially cases of oil spills that have disturbed the public. In the case of the Pertamina Company which caused the oil spill, we consider very urgently to analyze the problem: First, to what extent is the regulation of environmental protection, especially on natural oil and gas resources? Second, what is the form of accountability for the oil spill on the beach?

There are several studies concerning environmental pollution, particularly seawater pollution has been carried out. Elyazar, N., Mahendra, M. S., \&Wardi, I. N. (2015) indicates that seawater pollution also potentially caused by disposal of waste and the increase of human activities surrounding the seawater. The study of seawater contamination at Kuta Beach Bali shows that there has been a moderate level of pollution occurring as it is affected by the density of increased activity of human being in the area as well as the disposal of waste directly into the ocean waters. Protective measures are carried out through integrated and sustainable environmental conservation through waste management by the $3 R$ method and the dissemination of waste management facilities, conducting environmental audits, increasing supervision, monitoring of pollutant sources, community empowerment as a function of control, and firm law enforcement. ${ }^{2}$ Marine pollution also potential carry negative impact for the entire life of marine biota and their ecosystem. Therefore, protection and conservation of marine biota are constituted as an integral part of the marine protection in a broader context, then the parties responsible for the law enforcement to the protection of marine life and their ecosystem are the State and all related stakeholders including corporations. ${ }^{3}$ Although those studies mentioned previously concerning seawater pollution but this study more emphasizes to the accountability of parties related to the oil spill pollution, particularly accountability of the Pertamina in the petroleum spill case.

\section{Research Method}

The authors use normative juridical legal research methods, namely research on legal principles, legal rules and existing agreements to obtain information about the issues

\footnotetext{
2 Elyazar, N., Mahendra, M. S., \&Wardi, I. N. (2015). Dampak Aktivitas Masyarakat Terhadap Tingkat Pencemaran Air Laut Di Pantai Kuta Kabupaten Badung Serta Upaya Pelestarian Lingkungan. ECOTROPHIC: Jurnal Ilmu Lingkungan (Journal of Environmental Science). 2(1). p. 16-17

${ }^{3}$ Dharmawan, N.K.S., Sarjana, M. (2017). Marine Biota and Biodiversity: A Sustainable Tourism Perspective. Journal of Advances in Tropical Biodiversity and Environmental Sciences.1(1). p.16-17.
} 
raised by the author. Legal research is conducted to find solutions to legal issues that arise. The results achieved are to provide a prescription of what should on the issue posed. Legal research also means a process to discover the rule of law, legal principles, and legal doctrines to address the legal issues faced. ${ }^{4}$

\section{Result and Discussion.}

\subsection{Natural Resources Management: Regulation}

Megan Douglah on oil review concludes that: the society in which we presently live and colloquially consider to be "modern" would not be where it is today without constant innovation. From agriculture to meteorology, from medicine to robotics, the list is extensive, if not endless, and goes on into what some may consider perpetuity. Yet, the concept of innovation is nothing new. It is a byproduct of, and a natural response to, the ever-growing and ever-evolving challenges that confront the world and all those who live in it. Visionaries in science and technology, both past and present, have worked determinedly to solve the most prevalent challenges facing their respective eras. ${ }^{5}$

In Indonesia, the implementation of activities Article 33 of the 1945 Constitution is the root in the process of organizing and utilizing natural resources or production sector which controls the people, one of them is the oil and gas sector. ${ }^{6}$ It is mentioned in Article 33 paragraph (2) and paragraph (3) of the 1945 Constitution that: "production branches that are important for the state and which affect the livelihood of the masses are controlled by the state." Similarly $y_{L}$ the earth, water and natural resources contained therein are controlled by the state and used as great as possible for the prosperity and welfare of the people.

In the 1945 Constitution of the State of the Republic of Indonesia, paragraph 2 of article 33 explains "For the branches of production that are important to the State and who harvest the life of the people shall be controlled by the State".

Further mentioned:

a. Section 3 "The earth and the water and the natural resources contained therein are controlled by the state and used for the greatest prosperity of the people"

b. Section 4 "The national economy is organized on the basis of economic democracy with the principle of togetherness, efficiency, justice, sustainability, environmental insight, independence, and by maintaining a balance of progress and national economic unity".7

It is as a representation of Pancasila the philosophy of life of nation and state, where the founding father makes Pancasila by combining various ideology which one of them is socialist which focuses on social justice for every citizen.

\footnotetext{
${ }^{4}$ Mahmud, P. (2015). Penelitian Hukum. Prenada Media. Jakarta. p. 41

${ }^{5}$ Douglah M., (2017). Oil States Energy Services v. Greene's Energy Group: The Future of Inter Partes Review and Its Impact on the Energy Sector, https://digitalcommons.law.ou.edu/cgi/viewcontent.cgi?article=1138\&context=onej, March 2018 Vol 3 Number 6, p. 1344, accessed on 15 May 2018.

'Sunarya W, Ahmad G. T., (2017). Pengantar Hukum Minyak dan Gas Indonesia. Kantor Hukum Wibowo \& Rekan. Depok. p. 2

${ }^{7}$ Ibid. p. 12
} 
In Law No. 5 of 1960 on the Basic Agrarian Law (BAL), it has been explained how then the state acts as a regulator of its natural wealth. Arrange in the BAL referred to Article 2 paragraph (2) is

1. Organize and organize the use, stockpiling, and maintenance of the earth, water and space;

2. Regulate in terms of determining legal relationships between people and the earth, water, and space.

In the oil and gas sector, Indonesia uses socialist thinking where just economic management and prosperity must be implemented by the collective representation of a non-profit society.

\subsection{Natural Resource Management Policy}

Based on the records of revenues on state revenues it is found that the income of the state that has a large portion is in the areas related to the management of natural resources.

Regarding this issue, M. Kholid Syeirazi mentions that: 8 Indonesia is the country with the largest oil and gas reserves in Southeast Asia. According to data from the Ministry of Energy, until 2015 Indonesia has 60 hydrocarbon basins. 38 have been explored, while 22 others are still carried out exploration. Of basins have been explored, 16 basins already producing hydrocarbons, 9 basins have not produced even though it has been found hydrocarbon content, while the remaining 15 basins yet discovered hydrocarbon content.

Indonesia's National Development Planning Agency states: 9 "In 2001, the contribution of the natural resource sector to the national Gross Domestic Product (GDP) was about 30 percent with employment of 57 percent of total national employment." In addition, mineral and mining resources are among the sectors that contribute substantially in contributing to the national economy.

Indonesia's National Development Planning Agency added: “The contribution of oil and gas to government revenues in 2003, including oil and gas tax revenues reached $22.9 \%$ of total revenues. Due to the continuing decline in crude oil production capability, it is feared that the contribution is given by oil and gas also decreased." However, due to the exploitative use of natural resources and the environment, the balance and sustainability are disrupted. Therefore, in order to maintain the balance and sustainability has been done various steps and strategic actions according to the field of development covered in the development of natural resources and the environment. 10

Meanwhile, mining development also has the potential to contribute to environmental damage. The nature of the mining business (especially open pit

8 Zain., M. A. (2016). Politics of Law on the State Control of Oil and Gas in Indonesia: Gas Liberalization and the Hesitancy of Constitutional Court, Journal of Indonesian Legal Studies. 1 (1). p. 70

${ }_{9}^{9}$ Badan Perencanaan Pembangunan Nasional, Pembangunan Bidang Sumber Daya Alam dan Lingkungan Hidup, https://www.bappenas.go.id/files/4513/5228/2873/bab-xii-narasibidang-sumber-daya-alam--lingkungan-hidup_20081122044606_528.pdf, p. 1

${ }^{10}$ Ibid. p. 1 
mining) is to change the landscape so that it will cause changes in ecosystems and habitats. This change when it occurs on a large scale will cause disturbance of environmental balance that adversely affects human life. Another issue in the field of mining is the mine site's environmental damage due to the lack of handling of unused mining sites. In addition, increased mining activities without permits (call as PETI) also provide a complicated problem in improving the environment and on the sustainability of mine production. The case of mine landslides causing in gold mining in some locations is the result of illegal mining practices that are still difficult to control. ${ }^{11}$

The development of natural resources should not be released from awareness of environmental protection. Natural resource management is directed to improve the welfare of the people while taking into account the principles of sustainability of national development in the future. Mining Advocacy Network ${ }^{12}$ criticizing the management of Indonesia's natural resources, particularly in the oil and gas sector: "At the level of the implementation of oil and gas resources management is directed only for investment and export, so there is an indication of the legal politics of oil and gas sales, in the absence of oil and gas reserve resource strategy for the future needs of the people."

Symptoms of weakness and large disadvantages of unwise management lead to drastic decreases in the environment, as seen from climate change as a symptom of global warming. Examples of cases are: "an increase in the amount of atmospheric wastewater produced by agricultural, industrial and transport activities. Crossborder pollution such as smoke pollution from forest fires, mercury contamination, and oil at sea."13

The decline in quality and environmental carrying capacity is also affected by the global environmental damage. So, it becomes an obligation for the state and stakeholders who play a role in the efforts of natural resources management to be able to make breakthroughs in a more sustainable handling. The creation of a balance between the utilization and sustainability of natural resources and the environment is an important prerequisite for the sustainability of the development of natural resources and the environment. Utilization of controlled natural resources and environmentally friendly environmental management will be one of the most important basic capitals for overall national development. It is expected that the availability of natural resources can also contribute significantly to economic development.

In Indonesia, one of the breakthroughs on strengthening natural resources management policies can be seen in the vision statement inspired by the mandate contained in Article 3 of Law No.7 of 2004 on Water Resources on National Policy establishing the vision of natural resource management as follows: "Realization of natural resources that are managed in a fair, comprehensive, integrated, and environmentally sound way for the welfare of the people."

\footnotetext{
11Ibid. p. 3

${ }^{12}$ Majalah Jaringan Advokasi Tambang (2005). Kebijakan yang Melayani Permodalan. Maret 2005. p. 43

${ }^{13}$ Badan Perencanaan Pembangunan Nasional Op. Cit. p. 4
} 
With the commencement of sectoral policies in the form of natural resources is expected to be able to direct the goals and targets to be achieved in the development of natural resources and the environment are:

a. The recoverable condition of damaged natural resources and the environment;

b. Prevent the occurrence of damage to natural resources and the environment is more severe, so the rate of damage and pollution decreased;

c. Maintaining natural resources and the environment is still in good condition;

d. Increased environmental quality characterized by increasing

e. Ambient air quality and improved water quality in water bodies.

\subsection{Oil and Mining Policy}

In the oil and gas industry in Indonesia, from year to year, the production and consumption of Indonesian oil are not comparable ${ }^{14}$ where in 2017 oil consumption per day is 1.6 million barrels while the average oil production in Indonesia is 800.000 barrel per day. In addition, the government's policy to continue to provide subsidized fuel to the people is considered as a bad policy, where the target of the government is a society with a middle economy, but in fact, the economic community also enjoys the subsidies upwards. With government subsidies made from year to year felt very burdensome State Revenue and Expenditure Budget, this also makes Pertamina, as a state-owned Enterprise tends to only play the results of downstream exploration for operating costs.

If this condition is not immediately fixed, it is feared that Indonesia will experience dependence on oil from outside: The current condition of the Indonesian petroleum industry is not as bright as other energy industries such as natural gas or coal. Since peaking in 1995 with production of about 1.624 million barrels per day, petroleum production continues to decline to date. Petroleum production by 2015 is only 786,000 barrels per day, less than $50 \%$ of 1995 production levels. The production comes from old oil wells. As mentioned earlier that the weakening of investment in Indonesia is also occurring in the petroleum industry causing reduced exploration activities to find new oil sources. ${ }^{15}$

This is certainly different from other countries such as Malaysia with Petronas who benefit with the company's financial system, as well as research in the field of better technology so that it can do a competition to open a new mine until outside Malaysia (one of them in Indonesia). In addition, Petronas is supported by the Malaysian government in terms of investment as a comparison that profits earned by Petronas are largely given back for corporate development, and a small portion is given to the state. In Indonesi,Pertamina provides a large portion for state income other than taxes so that the results of benefits obtained Pertamina largely given back to the state, and a small part is given to Pertamina for the operation of the company including the search for new wells and technology development.

Other practice from New Zealand, Paul Foley oil and gas expertise, depicted the oil and gas ownership based on Crown Minerals Act 1991, Section 10; Continental Shelf

\footnotetext{
${ }^{14}$ Rista Rama Dhany, Ini Bukti Selisih Produksi Minyak RI dan Konsumsi BBM Makin Lebar, https:// finance.detik.com/energi/d-2946256/ini-bukti-selisih-produksi-minyak-ri-dankonsumsi-bbm-makin-lebar, accessed on 1 January 2018.

${ }^{15}$ Sekretariat Jenderal Dewan Energi Nasional (2016). Indonesia Energy Outlook 2016. p. 64.
} 
Act 1964, Section 30:16The Crown owns all of New Zealand's in-ground petroleum resources and has exclusive sovereign rights to petroleum resources in New Zealand's Exclusive Economic Zone and Continental Shelf. A permit must be obtained from the Crown to carry out any prospecting, exploration or mining activities. If extracted in the course of activities authorized by a permit, ownership of petroleum passes to the holder of that permit.

In the process of oil and gas mining must remain with the principle of maintaining ecosystem and environmentally friendly, so that the impact of mining does not interfere with the life of the people around the mining area. Vincent P. Wangelow has given the scrutiny of environment and oil that been tackle by EU:17

...To grasp the complex and interrelated legal environment in the EU regarding upstream petroleum operations, rationale and development of the respective rules must first be traced back on the European level. The EU Utilities Directives and the Hydrocarbon Licensing Directive are the most influential legal instruments in that respect.

If this principle is not implemented then the impact of mining that destroys the environment will be more detrimental to society and state, so that the initial principle of the holding of mining mandated in Article 33 of the 1945 Constitution as an effort for prosperity as much as possible for the people will also not be achieved. One that can threaten the environment from mining, especially oil and gas mining is the leakage of pipes. As one example of leakage of oil pipes in Balikpapan, with more focused oil exploration done offshore, the risk of environmental damage is also higher. In the case of a mine disaster, the role of the company as the manager and the government as the permit must be synergized. Law no. 24 of 2007 concerning Disaster Management in the case of weighing $b$ is explained "that the territory of the Unitary State of the Republic of Indonesia has geographical, geological, hydrological and demographic conditions which enable the occurrence of disasters, whether caused by natural factors, no natural factors, or human factors, the incidence of casualties, environmental damage, property loss, and psychological impacts that in certain circumstances can hamper social development." The United Nations Environment Programme (UNEP) stated:18 The exploitation of oil and gas reserves has not always been without some ecology side effects. Oil spills, damaged land, accidents and fires, and incidents of air and water pollution have all been recorded at various times and places.

In the case of a disaster as mentioned, any elements that may be involved should be mobilized to prevent and prevent the disaster from happening again. The problem is the division of authority over disaster management, especially the oil spill in

\footnotetext{
${ }^{16}$ Paul Foley, (2016) Oil \& Gas Law Review, Fourth Edition, Law Business Research Ltd, London, https://thelawreviews.co.uk/digital_assets/ac23c1b2-f6c9-4fd6-82a9270ac25669e3/TLR---Oil-\&-Gas---Fourth-Edition---Book-(UNSECURED).pdf, p. 195, accessed on 15 Juni 2018.

17 Wangelow., V. P. (2018). Petroleum licensing in the European Union: the allocation of E\&P rights in Denmark. The Journal of World Energy Law \& Business. 11(2). p. 1, accessed on 15 May 2018.

18 The United Nations Environment Programme (UNEP), Environmental Management on Oil and Gas Exploration and Production, p. 2.
} 
Balikpapan, so that both the local government and the central government does not occur overlapping authority.

As in Law no. 24 Year 2014 on Regional Government regional authority over mining has been revoked and returned to the central government both in terms of licensing and coordination in other mining fields. However, local governments can make regulations for environmental control, as described in However, local governments can make regulations for environmental control, as described in Article 13 of Law No. 32/2009 on the control of pollution and environmental degradation in the context of conservation of environmental functions, and environmental control, as a form of prevention. On the other hand, local governments can play an active role in terms of advocacy for losses received by the community due to disasters caused by a company. It can be acknowledged that the authority of the local government in terms of disasters, especially the impact of mining, can be said to be very poor. So, the coordination of the central government takes precedence as a form of government accountability to the community.

\subsection{Environmental Law}

Problems over the environment that has been happening bring the world community to pay more attention to environmental protection. In certain community groups, there is a sense that states that the environment as an asset. This is what causes preventive protection to prevent the occurrence of environmental damage tend to be very minimal. Even it is pointed out that in certain countries environmental awareness is lacking.

M.C. Mehta ${ }^{19}$ in the Book of Environmental Law ${ }^{20}$ stated: ... even categorize developed countries as 'over-consuming countries'. This will be very much different from the behavior of developed countries that emphasize more on environmental protection.

Therefore, if you want to follow the progress of developed countries then took several approaches like: 21

a. their creativity and technological innovation,

b. a development model that wants to return to nature,

c. use of environmentally friendly technologies, as well as

d. a strong learning and research culture.

With the perspective of the environment, it is expected that Indonesia will be able to become an established country in terms of the economy without sacrificing the existing environment.

Richard Stewart grouping the environmental concerns over:

a. Environmental pollution

b. Use and misuse of land (land misuse)

c. Dredging excessively causing depletion of natural resources (natural resource depletion)

${ }^{19}$ A Prominent Environmental Lawyers in India.

${ }^{20}$ Sarna, K. Maskun. \&Latif, B. (2014). Hukum Lingkungan (Teori, Legislasi dan Studi Kasus), USAID. p. xix

${ }^{21}$ Ibid.p. $\mathrm{xx}$ 
Based on the above-mentioned issues and related to the oil spill case in Kalimantan, it will be described further about the relationship between environmental protection (especially in marine waters) and the aspect of liability for pollution.

One important point of environmental protection and its surroundings is the level of implementation. What is interesting to us is that environmental protection not only covers only centralized level but also to the local level. The tendency to parallelize central and local policies can not necessarily work instantaneously but requires support from various parties. For example, in enforcing the implementation of REDD ${ }^{22}$ as a program of the United Nations Collaborative Program on Reducing Emissions from Deforestation and Forest Degradation in Developing Countries, gained some attitudes from the community:23

...there is pro and contra regarding REDD+ for local people. From positive side of REDD+, they tend to think that REDD+ could opening the opportunity for compensation...

Furthermore, Birkah Latif in Indonesia Law Review mentions:24

...the crucial issue "triangle tug war" between government of Indonesia, local communities and REDD+ mechanism itself.

Although there are conditions in the field such as phenomena mentioned above, still, local government as an extension at the local level is obliged to make efforts of approach and arrangement. These efforts can be seen in the protection of the marine environment and its surroundings are also known in traditional societies such as local communities around the Tanakeke Islands, Takalar Regency:

...which has the mention of the mangrove area as "bangkopanganreang" or bangkotappampang as a mangrove protection area whose existence must be maintained, should not be disturbed, should not be felled and should not be used at will...25

Thus, it can be seen the active participation of local communities in the success of environmental protection.

22 The REDD Desk stated:

REDD (reducing emissions from deforestation and forest degradation) incentivizes a break from historic trends of increasing deforestation rates and greenhouse gases emissions. It is a framework through which developing countries are rewarded financially for any emissions reductions achieved associated with a decrease in the conversion of forests to alternate land uses. Having identified current and/or projected rates of deforestation and forest degradation, a country taking remedial action to effectively reduce those rates will be financially rewarded relative to the extent of their achieved emissions reductions. See What is REDD+?, https:/ / theredddesk.org/what-redd, accessed on 15 June 2018.

In addition, The United Nations Collaborative Programme on Reducing Emissions from Deforestation and Forest Degradation in Developing Countries was launched in 2008 and builds on the convening role and technical expertise of the Food and Agriculture Organization of the United Nations (FAO), the United Nations Development Programme (UNDP) and the United Nations Environment Programme (UNEP).The UN-REDD Programme supports nationally led REDD+ processes and promotes the informed and meaningful involvement of all stakeholders, including indigenous peoples and other forestdependent communities, in national and international REDD+ implementation.

${ }^{23}$ Latif, B. (2016). Indonesian and Climate Change. JL Poll's \& Globalization. 45. 37. p. 41.

${ }^{24}$ Latif, B. (2015). Climate Change and Forest Governance: Lessons from Indonesia. Indonesia Law Review. 5(3). p. 347.

25 Irwansyah, I., Maskun, M., Latif, B., Rapy, I. (2012). Kajian Efektivitas Regulasi Pemanfaatan Hutan Mangrove di Kabupaten Takalar. Jurnal Penelitian Hukum, 2(1). p. 16. 


\subsection{Environmental Responsibility}

The regulation of responsibility for pollution of the marine environment is regulated in several international regulations. Phillipe Sands mentioned:26 "In the 1950s, the international community legislated on international oil pollution in the oceans. By the 1970s, the regional consequences of pollution and the destruction of flora and fauna were obvious, and by the late 1980s global environmental threats were part of the international community's agenda as scientific evidence identified the potential consequences of ozone depletion, climate change and loss of biodiversity."

A legal dispute settlement can also be an option for international legal subjects who are disputing with each other..$^{27}$

What is interesting in the discussion of oil pollution is the regulation of the International oil pollution compensation for fund ${ }^{28}$ Måns Jacobsson mentioned that: "The international regime for the compensation of pollution damage caused by oil spills from tankers is based on two treaties adopted under the auspices of the International Maritime Organization (IMO), the 1992 International Convention on Civil Liability for Oil Pollution Damage (1992 Civil Liability Convention), and the 1992 International Convention on the Establishment of an International Fund for Compensation for Oil Pollution Damage (1992 Fund Convention). These Conventions replace two corresponding Conventions adopted in 1969 and 1971 respectively."

Måns Jacobs son emphasizes that: ${ }^{29}$

a. The 1992 Civil Liability Convention governs the liability of shipowners for oil pollution damage. The Convention lays down the principle of strict liability for shipowners and creates a system of compulsory liability insurance. Shipowners are normally entitled to limit their liability to an amount which is linked to the tonnage of his ship.

b. The 1992 Fund Convention, which is supplementary to the 1992 Civil Liability Convention, set up an intergovernmental organization, the International Oil Pollution Compensation Fund (1992 Fund), which provides additional compensation to victims when compensation under the Civil Liability Convention is inadequate. By becoming a party to the Fund Convention, a State becomes a member of the 1992 Fund. The Organization has its headquarters in London.

There is also regulation of the United Nation Convention on The Law of the Sea 1982 (UNCLOS 1982) in Article 235 with the following arrangements:

a. States are responsible for the fulfillment of their international obligations concerning the protection and preservation of the marine environment. They shall be liable in accordance with international law.

b. States shall ensure that recourse is available in accordance with their legal systems for prompt and adequate compensation or other relief in respect of

${ }^{26}$ Sands, P. (2012). Principle of International Environmental Law $2^{\text {nd }}$ Edition. University Press. Cambridge. p.4

${ }^{27}$ Latif, B., Kadaruddin. (2013). Pengantar Hukum Internasional. Pustaka Pena Press. p. 34.

${ }^{28}$ Jacobs son, M. The International Oil Pollution Compensation Funds and the International Regime of Compensation for Oil Pollution Damage, Available from https://link.springer.com/chapter/10.1007/978-3-540-73396-6_11. p. 1.

${ }^{29}$ Ibid. 
damage caused by pollution of the marine environment by natural or judicial persons under their jurisdiction

c. With the objective of assuring prompt and adequate compensation in respect of all damage caused by pollution of the marine environment, State shall co-operate in the implementation of existing international law and the further development of international law relating to responsibility and liability for the assessment of and compensation for damage and the settlement of related disputes, as well as, where appropriate, development of criteria and procedures for payment of adequate compensation, such as compulsory insurance or compensation funds.

This international convention provides for the settlement of liability and damages for such pollution. Although it has been mentioned the arrangement through UNCLOS there are still weaknesses to cases that occur in the field. The provisions of the convention cannot be a direct solution because the existing provisions are not made in detail so they are not operational and still require other implementing arrangements.

In addition to the form of regulation regarding pollution through UNCLOS there are also Convention on Civil Liability for Oil Pollution Demarcation of Exploration For and Exploitation of Seabed Mineral Resources (CLEE 1977), International Convention on Civil Liability for Oil Pollution Damage 1969 (CLC 1969) and Basel Protocol on Liability and Compensation for Damage Resulting from Transboundary Movements of Hazardous Wastes and Their Disposal cannot be used for solving seabed oil mining oil-pollution problems.

Particularly for pollution occurring in seabed operations can be used through the Convention on Civil Liability for Oil Pollution Demarcation Resulting from Exploration For and Exploitation of Seabed Minerals Resources (CLEE 1977). The provisions of this Convention are more operational but the Convention is still in disadvantage because there is no regulation of state responsibility, but which is governed solely by responsibility by operators. This Convention provides for several matters relating to responsibilities, such as where accountability arises, who is responsible, in which case responsibility is waived, deadlines for compensation and other operational provisions.

In UNCLOS had been particularly mentioning concerning the implementation of marine pollution of a territorial territory of a country is as follows:

a. In its territorial sea, a coastal state may adopt legislation for the prevention, reduction, and control of marine pollution from foreign ships (art 211 (4))

b. The port state may prohibit a vessel from sailing if it is deemed to have violated international provisions and stamps relating to sea eligibility thereby posing a threat of damage to the marine environment (article 219)

c. In the event of any offense that causes or threatens to inflict serious damage on the coast or any natural resources in the territorial sea or its exclusive economic zone, in principle, it may also prosecute vessels, including its detention (section $220(6))$.

In addition to regulative rules, in International Law it is still charged to international actors of adherence to other sources of international law, that is, customary international law. 
... in the case of the Wimbledon (leased by France) vessel entering the waters of Kiel, Germany was then forbidden to pass, it was decided later by the International Court of Justice that Germany was not allowed to cross the voyage because it has been regulated in customary international law that the waters of Kiel are international waters so all the ship can pass through the canal..$^{30}$

In the Vienna Convention of 1969 on the law of covenant, in its last paragraph part of preamble:

"Affirming that the rules of customary international law will continue to govern questions not regulated by the provisions of the present conventions".

It is increasingly clear that the Vienna Convention requires that the International Code of Practice law be maintained as long as these matters are not or have not been regulated by the convention. ${ }^{31}$

\subsection{Corporate Responsibility}

The establishment of State-Owned Enterprises (hereinafter referred to as SOEs) is one of the government's efforts to realize the goal of the Indonesian state, namely "general welfare" in accordance with the mandate of the constitution. SOES itself is regulated in Law number 19 of 2003 on State-Owned Enterprises (hereinafter referred to as SOEs Law) and also on Law number 40 Year 2007 regarding Limited Liability Company (hereinafter referred to as UUPT) and other regulations. Article 9 of the SOES Law stipulates that SOES consists of a company and a public company whose legal entity is a limited liability company. This raises the logical consequence that the SOES with the form of the company is a legal entity.

As a legal entity, SOEs are legal subjects such as individuals who have rights and obligations, can perform legal acts, have their own wealth, can act in legal traffic with intermediaries of the board (organ) and can be held criminally and civil liability. So, it can be said that as one of the legal subjects all things directly or indirectly related to the Company can be held accountable including the social responsibility to the environment or Corporate Social Responsibility (hereinafter abbreviated as CSR).

\subsubsection{Corporate Criminal Responsibility}

In various Indonesian criminal law legislation, it is said that the corporation's understanding is an organized collection of persons and / or wealth whether it is a legal entity or not. In addition to Article 1 point 1 of Law Number 31 of 1999 on Corruption Eradication, determines that a corporation is a group of persons and/or assets organized either as a legal entity or not a legal entity. The corporation is nothing but an entity formed as a necessity to carry on an activity which is granted the status of a legal subject, in addition to the natural (human) subject matter. This corporation (legal entity) by law is recognized as a supporter of rights and obligations. Until now there is still a problem of corporate placement as a subject of crime. But now there are some laws and regulations that put the corporation as the subject of a crime. The development of corporate regulation as sub-subject of criminal acts and classified into 3 (three) system of responsibility, namely: ${ }^{32}$

\footnotetext{
${ }^{30}$ Latif, B., Kadaruddin., K. (2013). Hukum Perjanjian Internasional, Pustaka Pena Press. p. 73.

${ }^{31}$ Latif, B. (2011). Hukum Investasi: Kedudukan Bilateral Investment Treaties di Indonesia. Pustaka Pena Press. p. 64.

${ }^{32} \mathrm{Jacobs}$ son, M. The International Oil Pollution Compensation Funds and the International Regime of Compensation for Oil Pollution Damage, Op. Cit. p. 12
} 
a. Corporate Management as a Builder, So A Responsible Board

This accountability system is characterized by efforts to ensure that the nature of a corporation's criminal offensauthority or work relation

e is limited to individuals (naturlijk person). This system distinguishes caring and management duties.

b. Corporations as makers, then responsible Board

This system of accountability is characterized by the recognition that arises in the formulation of a law that a crime can be committed by a union or a corporation, but the responsibility for it becomes the burden of the legal entity (the corporation).

In this system of accountability, corporations may become criminal actors, but those responsible are members of the board, provided they are expressly stated in the rules.

c. Corporations as Creators as Responsible

This system of accountability is the beginning of a direct responsibility of the corporation. In this system, it opens the possibility of prosecuting the corporation and holding it accountable under the criminal law.

In addition to the corporate crime, two principles are known: ${ }^{33}$

a. The Strict Liability Principle (The Absolute Principle of Accountability)

According to this doctrine, a person can be held accountable for committing a particular crime even though the person is not guilty (mensrea), the important thing is that the act has fulfilled the formulation of the law or included in the act that is prohibited by law.

b. The Vicarious Liability Principle (Substitute Accountability Principle)

In this doctrine, the legal liability requirements of a legal entity are based on the existence of delegation of authority or work related and work performed by a person, which is still within the scope of business of that legal entity. Thus, the reasons that may be brought to the absence of a working relationship and or work are made out of the scope of business of that body of law.

Apart from these two principles, there are several theories used to find out who should be responsible:

a. Theory of Delegation of Authority

The purpose of this theory is the granting of authority to some administrators. The Board may be responsible if the board has or has been authorized or authorized in full in determining the policy and any attitudes of action against the corporate operations listed in the articles of association or corporate household budget.

b. Theory of Identification

The purpose of this theory is that the board must be identified or marked who has full authority or authority in determining the policy, making decisions and determining the actions that the corporation should take.

\subsubsection{Corporate Civil Liability}

Peter Roberts, stated: ${ }^{34}$...Under the common law doctrine of privity of contract, a contract generates rights and obligations only between the parties to the contract. A

${ }^{33}$ Hamdan, M. (2000). Tindak Pidana Pencemaran Lingkungan Hidup. Mandar Maju. Bandung. p. 96

${ }^{34}$ See Norman Nadorff, What Does English Law Say About.........? And the Winner Is: Book Review of Petroleum Contracts: English Law and Practice by Peter Roberts, Oil and Gas, Natural

Resources, and Energy Journal, 
third party will be a stranger to that contract and consequently, a contract cannot purport to confer a benefit on a third party which is enforceable by that third party directly against the contracting parties, nor can the contracting parties purport to enforce an obligation directly against a third party. These principles will hold true even if the contract expressly attempts to confer a benefit on the third party or if the third party knows of the obligation to which it is purportedly subject.

As a legal subject, the Limited Liability Company is also a person with rights and legal obligations, such as human beings; therefore, the Company may be held accountable for violations of law committed by the public. In the Civil Code (abbreviated KUHPerdata), Article 1365 states that; "any unlawful act that carries a loss to another person obliges the person because of the wrong to issue the loss, to compensate for the loss". Furthermore, Article 1366 KUHper determined that "Everyone is responsible not only for the harm caused by his actions but also because of his negligence or lack of care". In addition, of Article 1367 of the Civil Code holdsthat: "A person shall not only be liable for damages caused by his own deeds, but also for damages caused by the deeds of his dependents or by the goods under his control".

This provision is in line with the principle of vicarious liability. ${ }^{35}$ Thus, it can generally be inferred that civil liability can be interpreted as a legal consequence of the violation of rights and obligations, both rights and obligations born out of an agreement or born of law, ${ }^{36}$ or another person or body.

The Civil Liability in the form of Pinto's compensation, Liability (responsibility) indicates to the consequences arising from the consequences of failure to meet the standards, while the form of liability is realized in the form of compensation and recovery as a result of the occurrence of damage and loss. ${ }^{37}$ In the civil law itself the principles of responsibility can be distinguished as follows: ${ }^{38}$

1. The principle of responsibility based on the element of error (Liability based on fault)

In Indonesia, the principle of responsibility based on errors on the principle of concordat as set forth in Article 1365 of the Civil Code is known as the Law Against Act $(\mathrm{PMH})$, as for the elements of $\mathrm{PMH}$ as follows:

a. The existence of an element of unlawful acts of the defendant, as described above;

b. The act can be blamed on him;

https://digitalcommons.law.ou.edu/cgi/viewcontent.cgi?article=1146\&context=onej, p.4, accessed on 15 May 2018.

${ }^{35}$ Based on Henry Black's dictionary Vicarious liability is the employer's liability for the actions of the workers; or the principal's responsibility to the agent's actions in a contract.

${ }^{36}$ Indemnification is a reimbursement of costs, damages and Bonds for non-fulfillment of an agreement and its fulfillment is required if the debtor is declared negligent (Article 1234 KHUPER). The elements of loss according to the provisions of Article 1246 of the Criminal Code consists of 3 (three) elements, namely: 1) Costs, i.e. all expenses or fees that have obviously been issued; 2) Loss, i.e. loss due to damage to the creditor's possessions caused by the debtor's negligence; and 3) Interest, i.e. the profit that should be obtained or expected by the creditor if the debtor is not negligent.

${ }^{37}$ Juanda quoted from Wahyudi, S. \& Asheri, B. (2008). Corporate Social Responsibility: Prinsip, Pengaturan dan Implementasinya. Setara Press dan INSPIRE. Malang. p. 4

${ }^{38}$ Ibid. 
c. The loss suffered by the plaintiff as a result of the error.

2. The principle of Responsibility based on Presumption of Liability

The principle of responsibility is also based on error, but with emphasis on the reversal of the burden of proof (Shifting of the burden of proof to the defendant). If this principle is drawn to corporate responsibility, if the public feels aggrieved by a company, either from corporate activity or because of its existence. The community can directly sue and the company later that proves that the losses suffered by society are not due to the fault of the corporation in question.

3. Absolute Liability or Strict Liability

The birth of this absolute responsibility "onrechmatigedaad" which emphasizes the element of error, in other words must, be a provision of legislation that is violated, in fact, empirical not all elements of error (fault) can be proven, even some that cannot be proved at all. It is a form of civil liability that does not require the provision of fault elements, as the main element in accounting for civil cases in the event of fault based. By the term of proof of causality in which people who feel aggrieved do not need to prove the wrong done but burdened to prove the loss experienced due to corporate activity.

Due to unlawful acts committed by a person then there is the interest of others who feel harmed. In other words that the party committing the act unlawfully shall be responsible for the loss suffered by that other person. This also applies to corporations, it can be concluded that any actions of the parties that include unlawful acts that result in harm to the other party, then the law can be held to civil liability by filing a lawsuit to the court. Based on the principle of absolute responsibility does not need to be considered whether the cause is due to deliberate or because of negligence. The civil liability and compensation that must be borne by those who commit the act unlawfully is only a direct loss of unlawful acts committed and felt by the public.

\subsubsection{Corporate Social and Environmental Responsibility (CSER)}

Corporate Social Responsibility or better known as CSR (hereinafter referred to as CESR) is a term often used in conjunction with the implementation of Corporate Social Responsibility (CESR). This responsibility is generally regulated in the Law of Limited Liability Company (UUPT), namely Law no. 40 of 2007 referred to in Article 1 number 3 namely; "Social and Environmental Responsibility is the Company's commitment to participate in sustainable economic development in order to improve the quality of life and the environment that is beneficial to both the Company itself, the local community and the community at large".

The definition in Article 1 only states that the CESR is a commitment of the company, the provision requiring the company to perform the CESR stated in Article 74 but in fact, only specializes in companies whose business activities in the field and/or related to natural resources. Further mentioned that this obligation should be budgeted and calculated as the cost of the company. Thus, it can be concluded that this activity should be implemented in a planned manner. The law itself does not impose specific types of sanctions if the company does not implement the CESR.

Regulation of CESR Implementation is regulated through Government Regulation no. 47 of 2012 on Corporate Social Responsibility and Environment Limited. The Government Regulation consisting of these nine articles can be said to have only slightly expanded the picture of what the company CESR meant. Social 
responsibility is called inherent in every company, but in particular, the obligation is placed on the company conducting its business activities in the field and/or related to natural resources. It means companies whose business is managing and utilizing natural resources directly or companies that do not manage and do not utilize natural resources, but business activities have an impact on the function of natural resource capability including the preservation of environmental functions. This Government Regulation then regulates the mechanism of the CESR decision process within the company but still does not provide a more adequate provision of what is the scope of CESR, companies whose fields of business are related to natural resources, and who oversees the implementation of CESR by the company. Regarding sanctions, this Government Regulation as well as the UUPT, which is its parent, only refer to the relevant legislation that in its description is mentioned quite broadly. ${ }^{39}$

It may be mentioned that the relevant laws and regulations governing CESR are included in Law no. 25 Year 2007 on Investment (hereinafter referred to as UUPM). Article 15-letter $b$ provides that the CESR is attached to every Investor. UUPM provides a definition of Investor covering individual (WNI or WNA) or company conducting domestic or foreign investment. However, in the explanation, it is only mentioned that CESR is the responsibility attached to each investment company to keep creating a harmonious, balanced, and appropriate relationship with the environment, values, norms, and culture of the local community. UUPM actually provides rules on sanctions if the company does not implement this obligation, among others: 1) Written warning; 2) Restrictions on business activities; 3) Freezing of business activities and/or investment facilities, or 4) Revocation of business activities and/or investment facilities.

Furthermore, in Law Number 22 Year 2001 on Oil and Gas does not explicitly regulate corporate social responsibility. However, when reading carefully, there is one rule that is implicitly touched on CESR. The provision is Article 11 paragraph (3) letter $\mathrm{p}$, which reads,"The Cooperation Contract referred to in paragraph (1) shall contain a few basic provisions: the development of the surrounding community and the guarantee of the rights of indigenous peoples."

In addition to Law Number 32 Year of Year 2009 on Environmental Protection and Management (hereinafter referred to as UUPPLH) in the third section on Environmental Dispute Settlement through Courts in Article 88 determine that;"Any person whose actions, efforts and / or activities use B3, produce and / or manage B3 waste, and/or poses a serious threat to the environment responsible for absolute losses without any evidence of error".

In Article 88 it determines the absolute liability by the Company that performs actions, businesses and / or activities that have the potential and/or damage to the environment. This UUPPLH has specifically been explained about who can file an expiry deadline for filing a lawsuit as well as technical and non-technical matters, which can be applied to a company that commits environmental pollution.

39 See Government Regulation no. 47 of 2012 on Corporate Social Responsibility and Environment Limited. 
In the case of a leak of the regional Pertamina pipeline of East Kalimantan caused by a Panama-flagged coal vessel MV Ever Judger when it is associated with Criminal, Civil and Corporate Responsibility, PT Pertamina may be charged the Strict Liability or Absolute Liability because according to this doctrine, a person (legal entity) may be held accountable even if the person is not in error (mensrea), the important thing is that the act has fulfilled the formulation of law or included in the act which is prohibited by law and the loss has been felt by the society without need the proving of errors made due to corporate activity.

However, in relation to the existence of errors caused by the shipowner MV operator Ever Judger who should comply with the sea-channel flow applied by the Indonesian government as well as the regulation of submarine pipe laying is mandatory for sea passengers to be careful in carrying out its cross operations.

With the provisions of UNCLOS, which impose on the territory state if there is oil contamination within its territory, then in effect $t_{L}$ it is the national provision of the country subject to the polluted condition.

in line with the Environmental Management Law of 2009, it is determined that in this strict liability principle there is no need to prove the error because the error is factual, in accordance with the concept of strict liability itself. Persons affected by pollution due to oil spills caused by ships may claim compensation (liability) against the company MV Ever Judger with estimated total losses incurred by government agencies, especially the ministry of the environment.

\section{Conclusion}

The use of natural resources, which produce metals, coal, and minerals as a source of energy, oil and geothermal, should be based on the principles of environmental management, namely: equity, balances, democracy (democracy), and sustainability (sustainable) between generations. This management will be implemented properly if it is poured into a state policy that involves all stakeholders (stakeholder) in an optimal way with a partnership pattern. Based on the principle of management, the government policy in the field of natural resources must be characterized by environmentally sustainable (sustainable) and lead to "social justice and equality".

If it is viewed in terms of accountability both in civil liability, criminal, and the environment in accordance with the principle of direct liability (strict liability) with the occurrence of environmental pollution caused by the oil spill so legally PT Pertamina Regional East Kalimantan may be subject to the principle. However, disregarding the principle of direct accountability is the proof of error that caused the oil spill not to be directly charged to PT Pertamina, because the pipeline damage was caused by anchorage of the Panama-flagged coal-fired MV Ever Judger. For further verification, it is necessary to conduct more in-depth and technical review to know factually related to the case.

\section{Acknowledgments}

This work has been successfully completed as a form of academic cooperation to analyze environmental issues and development of oil and gas management, pollution and marine issues.

This work is a collaboration of three authors who will continue to work in contributing to existing legal issues. 


\section{References}

Books

Abdulrahman, S. Outlook energy Indonesia 2015". Sekretaris Jenderal Dewan Energi Nasional, ISSN, 2503-1597.

Hamdan, M. (2000). Tindak Pidana Pencemaran Lingkungan Hidup. Bandung: Mandar Maju.

Latif, B. (2011), Hukum Investasi: Kedudukan Bilateral Investment Treaties di Indonesia, Pustaka Pena Press.

Latif, B., Kadaruddin, K. (2013), Pengantar Hukum Internasional. Pustaka Pena Press,

Latif, B., Kadaruddin, K. (2013),.Hukum Perjanjian Internasional. Pustaka Pena Press,

Marzuki, P. M. (2015). Penelitian Hukum. Jakarta: Prenada Media.

Marzuki, P. M. (2011). Penelitian Hukum. Jakarta: Prenada Media.

Paul Foley, (2016) Oil \& Gas Law Review, Fourth Edition, Law Business Research Ltd, London, https://thelawreviews.co.uk/digital_assets/ac23c1b2-f6c94fd6-82a9-270ac25669e3/TLR---Oil-\&-Gas---Fourth-Edition---Book(UNSECURED).pdf. accessed on 15 Juni 2018.

Sands, P., \& Peel, J. (2012). Principles of international environmental law. Cambridge University Press.

Sarna, K. Maskun. \&Latif, B. (2014). Hukum Lingkungan (Teori, Legislasi dan Studi Kasus), USAID.

Setiyono, H. (2003). Kejahatan Korporasi: Analisis Viktimologis dan Pertanggungjawaban Korporasi dalam Hukum Pidana Indonesia. Malang: Bayumedia Publishing.

Sunarya W, Ahmad G. T., (2017). Pengantar Hukum Minyak dan Gas Indonesia. Depok: Kantor Hukum Wibowo \& Rekan.

The United Nations Environment Programme, (1997), Environmental Management on Oil and Gas Exploration and Production.

Wahyudi, I., \& Azheri, B. (2008). Corporate social responsibility: Prinsip, pengaturan dan implementasi. Institute for Strengthening Transition Society Studies (In-Trans Institute): Institute for Supporting Programe Institution and Research Development (Inspire).

\section{Journal}

Dharmawan, N. K. S., \& Sarjana, M. (2017). Marine Biota and Biodiversity: A Sustainable Tourism Perspective. Advances in Tropical Biodiversity and Environmental Sciences, 1(1), 18-22. 
Douglah, M. (2017). Oil States Energy Services v. Greene's Energy Group: The Future of Inter Parties Review and its Impact on the Energy Sector. ONE J, 3, 1343.

Elyazar, N., Mahendra, M. S., \&Wardi, I. N. (2015). Dampak Aktivitas Masyarakat Terhadap Tingkat Pencemaran Air Laut Di Pantai Kuta Kabupaten Badung Serta UpayaPelestarianLingkungan. ECOTROPHIC: Jurnal Ilmu Lingkungan (Journal of Environmental Science). 2(1).

Iswansyah, M., Maskun, M., Latif, B., \& Rapy, I. (2013). Kajian Efektivitas Regulasi Pemanfaatan Hutan Mangrove Di Kabupaten Takalar. [89] Jurnal Penelitian Hukum: Fh Univ. Hasanuddin, 2(1).

Jacobsson, M. (2007). The International oil pollution compensation funds and the international regime of compensation for oil pollution damage. In Pollution of the Sea-Prevention and Compensation (pp. 137-150). Springer, Berlin, Heidelberg. https://doi.org/10.1007/978-3-540-73396-6_11

Latif, B. (2016). Indonesian and Climate Change. JL Pol'y \& Globalization, 45, 37.

Latif, B. (2015). Climate Change and Forest Governance: Lessons from Indonesia. Indonesia Law Review. 5(3). http://dx.doi.org/10.15742/ilrev.v5n3.188

Majalah Jaringan Advokasi Tambang. (2005). Kebijakan yang melayani pemodal.

Nadorff, N. (2018). What Does English Law Say About........? And the Winner Is: Book Review of Petroleum Contracts: English Law and Practice by Peter Roberts. Oil and Gas, Natural Resources, and Energy Journal, 4(1), 1.

Siagian, Y. S., Rifai, A., \& Ismanto, A. (2016). Pemodelan Sebaran Tumpahan Minyak Di Perairan Teluk Balikpapan, Kalimantan Timur. Journal of Oceanography, 5(2), 270-276.

Wangelow, V. P. (2018). Petroleum licensing in the European Union: the allocation of E\&P rights in Denmark. The Journal of World Energy Law \& Business, 11(2), 145163. https://doi.org/10.1093/jwelb/jwy004

Zain, M. A. (2016). Politics of Law on the State Control of Oil and Gas in Indonesia: Gas Liberalization and the Hesitancy of Constitutional Court. JILS, 1, 69.

Internet

Badan Perencanaan Pembangunan Nasional, Pembangunan Bidang Sumber Daya Alam dan Lingkungan Hidup, Retrieved from https:// www.bappenas.go.id/files/4513/5228/2873/bab-xii-narasi-bidangsumber-daya-alam--lingkungan-hidup_20081122044606_528.pdf. Accessed 8 Juni 2018.

Dhany R.R. ,Ini Bukti Selisih ProduksiMinyak RI dan Konsumsi BBM Makin Lebar, https:// finance.detik.com/energi/d-2946256/ini-bukti-selisih-produksiminyak-ri-dan-konsumsi-bbm-makin-lebar, accesed on 1 January 2018. 
Foley P, (2016) Oil \& Gas Law Review, Fourth Edition, Law Business Research Ltd, London, https://thelawreviews.co.uk/digital_assets/ac23c1b2-f6c9-4fd682a9-270ac25669e3/TLR---Oil-\&-Gas---Fourth-Edition---Book-

(UNSECURED).pdf, p. 195, accessed on 15 Juni 2018

Erni Herawati. (desember 2016). law.binus.ac.id/2016/12/29/penguatan-tanggung-jawab-sosial-danlingkungan-perusahaan-di-indonesia/. accessed pada 8 Juni 2018.

PT. Asahimas Flat Glass Tbk. http://www.amfg.co.id/id/tanggung-jawabsosial/jenis-program/tanggung-jawab-terhadap-lingkungan.html. accessed pada 8 Juni 2018.

Hasyry Agustin. (2017, Februari 8). Gunakan Strict Liability, Hakim Hukum Perusahaan Ini Ratusan Miliar. Hukum Online . http://www.hukumonline.com/berita/baca/lt589a96375f9f4/gunakanistrict-liability-i--hakim-hukum-perusahaan-ini-ratusan-miliar. accessed pada 8 Juni 2018.

Klinik. (2013, November 13). Hukum online.com. http://www.hukumonline.com/klinik/detail/lt52716870e6a0f/aturanaturan-hukum-corporate-social-responsibility. accessed pada 8 Juni 2018.

Pusat datar Hukum online.com. http://www.hukumonline.com/pusatdata/view/node/lt52df7d0b575ea . accessed pada 8 Juni 2018.

KlinikLegal.com. (2017, Juli 17). Mengenal Sejumlah Regulasi yang Mengatur CSR di Indonesia. $\quad$ https://kliklegal.com/mengenal-sejumlah-regulasi-yangmengatur-csr-di-indonesia/. accessed pada 8 Juni 2018.

Naufal. (2017, maret 5). Slide share. https://www.slideshare.net/ReyziCaniago/tanggung-jawab-sosial-danlingkungan-perusahaan . accessed pada 8 Juni 2018.

\section{$\underline{\text { Tesis / Desertasi }}$}

Fitriany, M. (2016). Pengaturan Tanggung Jawab Pemerintah Australia Terhadap Pencemaran Laut Lintas Batas Sebagai Akibat Seabed Oil Mining Yang Merugikan Indonesia (Studi Kasus Pencemaran Lintas Batas Oleh PT. T. Exploration And Production Australasia) (Doctoral Dissertation, UAJY).

Mosley, E. C. (2018). The Commodification of Nature: Power/Knowledge and REDD+ in Costa Rica (Doctoral dissertation, Virginia Tech

Alofnso F Pahotan Napitupulu, S. H., \& Sulistiowati, S. H. (2015). Pertanggungjawaban Korporasi Secara Perdata Dalam Perbuatan Melawan Hukum Yang Mengakibatkan Kerusakan Lingkungan Oleh PT Lapindo Brantas (Doctoral Dissertation, Universitas Gadjah Mada). 
P-ISSN:,2302-528X, E-ISSN: 2502-3101

\section{Legal Documents}

Kitab Undang-Undang Hukum Perdata

Undang-Undang No. 31 Tahun 1999 tentang Tindak Pidana Korupsi.

Undang-Undang No. 22 Tahun 2001 Tentang Minyak Dan Gas Bumi.

Undang-Undang No. 19 Tahun 2003 tentang Badan Usaha Milik Negara.

Undang-Undang No. 24 Tahun 2007 Tentang Penangulangan Bencana

Undang-Undang No. 40 Tahun 2007 tentang Perseroan Terbatas.

Undang-Undang No. 25 Tahun 2007 tentang Penanaman Modal.

Undang-Undang No. 32 Tahun 2009 tentang Perlindungan Dan Pengelolaan Lingkungan Hidup.

Peraturan Pemerintah No. 47 Tahun 2012 tentang Tanggung Jawab Sosial Dan Lingkungan Perseroan Terbatas.

\section{Dictionary}

Henry Black's dictionary 